\title{
Front Matter: Volume 9928
}

, "Front Matter: Volume 9928," Proc. SPIE 9928, Nanobiosystems: Processing, Characterization, and Applications IX, 992801 (23 November 2016); doi: $10.1117 / 12.2258083$

SPIE Event: SPIE Nanoscience + Engineering, 2016, San Diego, California, United SPIE. States 


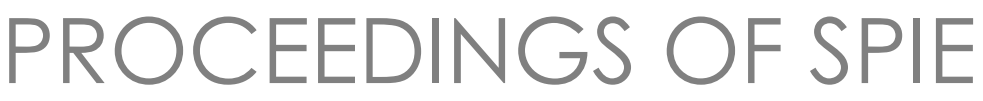

\title{
Nanobiosystems: Processing, Characterization, and Applications IX
}

\author{
Norihisa Kobayashi \\ Fahima Ouchen \\ Ileana Rau \\ Editors
}

28-31 August 2016

San Diego, California, United States

Sponsored and Published by

SPIE 
The papers in this volume were part of the technical conference cited on the cover and title page. Papers were selected and subject to review by the editors and conference program committee. Some conference presentations may not be available for publication. Additional papers and presentation recordings may be available online in the SPIE Digital Library at SPIEDigitallibrary.org.

The papers reflect the work and thoughts of the authors and are published herein as submitted. The publisher is not responsible for the validity of the information or for any outcomes resulting from reliance thereon.

Please use the following format to cite material from these proceedings:

Author(s), "Title of Paper," in Nanobiosystems: Processing, Characterization, and Applications IX, edited by Norihisa Kobayashi, Fahima Ouchen, lleana Rau, Proceedings of SPIE Vol. 9928 (SPIE, Bellingham, WA, 2016) Six-digit Article CID Number.

ISSN: 0277-786X

ISSN: 1996-786X (electronic)

ISBN: 9781510602472

ISBN: 9781510602489 (electronic)

Published by

SPIE

P.O. Box 10, Bellingham, Washington 98227-0010 USA

Telephone +1 3606763290 (Pacific Time) · Fax +1 3606471445

SPIE.org

Copyright @ 2016, Society of Photo-Optical Instrumentation Engineers.

Copying of material in this book for internal or personal use, or for the internal or personal use of specific clients, beyond the fair use provisions granted by the U.S. Copyright Law is authorized by SPIE subject to payment of copying fees. The Transactional Reporting Service base fee for this volume is $\$ 18.00$ per article (or portion thereof), which should be paid directly to the Copyright Clearance Center (CCC), 222 Rosewood Drive, Danvers, MA 01923. Payment may also be made electronically through CCC Online at copyright.com. Other copying for republication, resale, advertising or promotion, or any form of systematic or multiple reproduction of any material in this book is prohibited except with permission in writing from the publisher. The CCC fee code is 0277-786X/16/\$18.00.

Printed in the United States of America.

Publication of record for individual papers is online in the SPIE Digital Library.

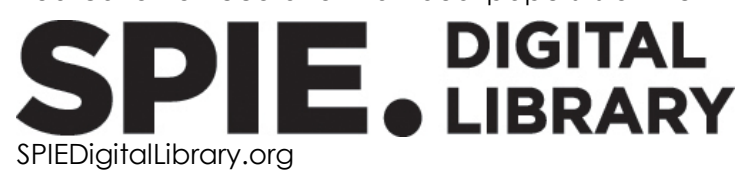

Paper Numbering: Proceedings of SPIE follow an e-First publication model. A unique citation identifier (CID) number is assigned to each article at the time of publication. Utilization of CIDs allows articles to be fully citable as soon as they are published online, and connects the same identifier to all online and print versions of the publication. SPIE uses a six-digit CID article numbering system structured as follows:

- The first four digits correspond to the SPIE volume number.

- The last two digits indicate publication order within the volume using a Base 36 numbering

system employing both numerals and letters. These two-number sets start with $00,01,02,03,04$, 05, 06, 07, 08, 09, OA, OB ... 0Z, followed by 10-1Z, 20-2Z, etc. The CID Number appears on each page of the manuscript. 


\title{
Contents
}

\author{
$\checkmark$ Authors \\ vii Conference Committee
}

\section{DNA PHOTONICS I}

992802 Effect of charge carrier blocking layers on poling nonlinear optic polymers (Invited Paper) [9928-1]

\section{DNA PHOTONICS II}

992806 DNA-based dye lasers: progress in this half a decade (Keynote Paper) [9928-5]

992807 Dynamical light scattering for DNA-CTMA:DR1 chains: wormlike semi-flexible model, coil size and persistence length (Keynote Paper) [9928-6]

992808 Deoxyribonucleic acid (DNA)-Ni-nanostrands composites for EMI shielding [9928-7]

992809 Tunable lasers based on hemicyanines embedded in DNA complex [9928-8]

\section{BIOMATERIALS ELECTRONICS}

9928 OC Analysis and optimization of the two-channel SPR interferometer sensor design (Invited Paper) [9928-11]

\section{NANOMATERIALS I}

$9928 \mathrm{OE}$ Biomimetic $\mathrm{TiO}_{2}$ formation from interfacial sol-gel chemistry leading to new photocatalysts [9928-13]

9928 OF Preparation and optical characterization of DNA-riboflavin thin films [9928-14]

\section{NANOMATERIALS II}

9928 ON First-order Judd-Ofelt optical characterization of DNA-Ln3+ complexes (Invited Paper) [9928-23] 
POSTER SESSION

992800 Laser-assisted synthesis of ultrapure nanostructures for biological sensing applications [9928-25]

9928 OP Biomimetic tissue platform for photothermal cancer therapy using gold nanorods (GNRs) [9928-26] 


\title{
Authors
}

Numbers in the index correspond to the last two digits of the six-digit citation identifier (CID) article numbering system used in Proceedings of SPIE. The first four digits reflect the volume number. Base 36 numbering is employed for the last two digits and indicates the order of articles within the volume. Numbers start with 00, 01, 02, 03, 04, 05, 06, 07, 08, 09, 0A, 0B...0Z, followed by 10-1Z, 20-2Z, etc.

\author{
Bae, Ji Yong, OP \\ Bagga, Komal, 00 \\ Brabazon, Dermot, 00 \\ Brasi, Quentin, 00 \\ Chang, Ki-Soo, OP \\ Cheon, Seungwuk, ON \\ Coussy, Julie, 00 \\ Dalton, Larry, 02 \\ Dugasani, Sreekantha Reddy, OF, ON \\ Grote, James G., 02, 08, 0C \\ Heckman, Emily, 02 \\ Jaffer Al-Timimi, Iman A., OE \\ Jeong, Chan Bae, OP \\ Joo, Boram, OF \\ Jung, Woohyun, OF \\ Kajzar, François, 02, 07 \\ Kawabe, Yutaka, 06, 09 \\ Khazaeinezhad, Reza, OF \\ Kim, Gunhee, OP \\ Kong, Byungjoo, OF \\ Lazar, C. A., 07 \\ Lee, Kye-Sung, OP \\ McCann, Ronán, 00 \\ Mitus, A. C., 07 \\ Nam, Ki-Hwan, OP \\ Oh, Kyunghwan, OF, ON \\ Onwukwe, Uche K., OE \\ Ouchen, Fahima, 02, 08, 0C \\ Paulson, Bjorn, OF, ON \\ Pawlik, G., 07 \\ Radosz, W., 07 \\ Rau, lleana, 02, 07 \\ Salour, Michael M., 08 \\ Saver, Gregor, OF, ON \\ Sermon, Paul A., OE \\ Shin, Inchul, OF \\ Stalcup, Apryll, 00 \\ Suzuki, Yuki, 09 \\ Vázquez, Mercedes, 00 \\ Wilson, Benjamin G., 08 \\ Worsley, Myles P., OE \\ Yaney, Perry P., 08, 0C
}


Proc. of SPIE Vol. $9928992801-6$

Downloaded From: https://www.spiedigitallibrary.org/conference-proceedings-of-spie on 26 Apr 2023 Terms of Use: https://www.spiedigitallibrary.org/terms-of-use 


\title{
Conference Committee
}

\author{
Symposium Chairs
}

Harry A. Atwater, Jr., California Institute of Technology (United States)

Nikolay I. Zheludev, Optoelectronics Research Centre

(United Kingdom) and Nanyang Technological University

(Singapore)

Symposium Co-chairs

David L. Andrews, University of East Anglia (United Kingdom)

James G. Grote, Air Force Research Laboratory (United States)

Conference Chairs

Norihisa Kobayashi, Chiba University (Japan)

Fahima Ouchen, Air Force Research Laboratory (United States)

lleana Rau, Universitatea Politehnica din Bucuresti (Romania)

Conference Program Committee

Carrie M. Bartsch, Air Force Research Laboratory (United States)

Liming Dai, Case Western Reserve University (United States)

Ananth Dodabalapur, The University of Texas at Austin (United States)

James G. Grote, Air Force Research Laboratory (United States)

Emily M. Heckman, Air Force Research Laboratory (United States)

Kuniharu ljiro, Hokkaido University (Japan)

Jung-II Jin, Korea University (Korea, Republic of)

Francois Kajzar, Universitatea Politehnica din Bucuresti (Romania)

Sang Nyon Kim, Air Force Research Laboratory (United States)

Oksana Krupka, Université d'Angers (France)

Charles Y. C. Lee, Air Force Office of Scientific Research

(United States)

Misoon Y. Mah, Asian Office of Aerospace Research and

Development (Japan)

Bruce H. Robinson, University of Washington (United States)

Anna Samoc, The Australian National University (Australia)

Marek J. Samoc, Wrocław University of Technology (Poland)

Niyazi Serdar Sariciftci, Johannes Kepler Universität Linz (Austria)

Kristi M. Singh, Air Force Research Laboratory (United States)

Andrew J. Steckl, University of Cincinnati (United States)

Morley O. Stone, Air Force Research Laboratory (United States)

Guru Subramanyam, University of Dayton (United States)

Perry P. Yaney, University of Dayton (United States) 


\section{Session Chairs}

1 DNA Photonics I

lleana Rau, Universitatea Politehnica din Bucuresti (Romania)

2 DNA Photonics II

Jaroslaw Mysliwiec, Wrocław University of Technology (Poland)

3 Biomaterials Electronics

François Kajzar, Universitatea Politehnica din Bucuresti (Romania)

4 Nanomaterials I

Norihisa Kobayashi, Chiba University (Japan)

5 Biomaterials

Donna M. Joyce, Air Force Research Laboratory (United States)

6 Nanomaterials II

Fahima Ouchen, Air Force Research Laboratory (United States) 